\title{
Perception of Villa Manager on Using the Online Travel Agents as Marketing Media in North Kuta District, Badung, Bali, Indonesia
}

\author{
Made Antara \\ University of Udayana, \\ Bali, Indonesia
}

\author{
Nyoman Madiun \\ Bali Tourism High Education \\ Institute, Bali, Indonesia
}

\author{
Luh Sri Astuti \\ Bali Provincial Government, \\ Indonesia
}

\begin{abstract}
The development of villas in Bali is very rapid, especially in Badung regency with the distribution of the number of dominant villas in North Kuta district. Based on preliminary study, tourists tend to make reservations through online travel agents (OTA). Therefore, there is a tendency if the villa manager in North Kuta district makes promotion through OTA. The aim of this research is to explain and analyze the dominant factors that influence the perception of villa managers in North Kuta district on using OTA as marketing media. The population in this research is composed of 191 villas. The final sample villas, using Slovin formula, were chosen based on cluster proportional sampling technique, totally 66 unit villas. Respondent in this research is the villa manager of each sample villa, so there are as much as 66 respondents. For data analysis, we used confirmatory factor analysis and descriptive statistics. In general, the perception of managers in North Kuta district on the use of OTA as marketing media is strongly agree or strongly positive with an average value of 4.37. The analysis of factors simultaneously showed that the perception of villa managers in North Kuta district on the use of OTA is determined by three factors, namely, factor in the self-perception of villa manager (F1), the factors in the self-perception of OTA (F2), and situational factors (F3).
\end{abstract}

Keywords: perception, villa manager, online travel agents (OTA)

\section{Introduction}

Tourism in Bali in the last three decades has been growing very rapidly demonstrated by an increase in the number of foreign and domestic tourist arrivals. Based on the Bali BPS web publications (November 19, 2015), in 1990, tourist arrivals to Bali just are as many as 489,710 people, in 2000 increased to 1,412,839 people, and in 2013 jumped to 3,278,598 people. Increased tourist arrivals mean that more accommodations will be required.

The accommodation sector in Bali is growing very rapidly with the increase in tourist arrivals, ranging between hotel, homestay, villas and other accommodation types. According to Ismoyo (2011), there is a shift mode of tourism from mass tourism to individual tourism where tourists prefer to stay in a villa for more personal experience. Shift mode of tourism can be seen from the tourists who prefer to live in a more private villa, mainly tourists in pairs or couple and honeymoon tourists. Shift mode of tourism has led to the increasingly rapid growth of villas.

Made Antara, lecturer at Tourism Doctoral Program, University of Udayana. Email: antara_unud@yahoo.com. Nyoman Madiun, lecturer of Tourism Management, Bali Tourism High Education Institute. Luh Sri Astuti, official of Bali Provincial Government. 
The development of villas in Bali is very rapid, especially in Badung regency. The number of villas in Badung regency in 2009 was recorded to be 73, which increased to 158 units in year 2010, 293 units in year 2011, 414 units in year 2012, and finally 460 units in July 2013. However, from 460 units who have business licenses, $41.52 \%$ of them are located in the district of North Kuta (Badung Tourism Agency, 2013). However, Evita, Sirtha, and Sunarta (2012) explained that the spread of villas in the Badung regency is dominant in the district of North Kuta.

Growth in the number of villas is very rapid, leading also to the increased competition on the business property. One competition between businesses villas can be seen from a very tight competition in getting potential customers. Various marketing, especially promotion efforts have been made by the villa industry. Promotional efforts are conducted through various promotion methods like personal selling, sales promotion, direct marketing, advertising, and online marketing is one of them through online travel agents (OTA). Another promotional medium used is through online marketing media, such as by using the website, blogs, and social media. According to Kotler (2000) and Kotler and Armstrong (2012), the advantages of online direct marketing include: reducing the cost of financing such as the rental cost of purchasing a store, can make efficiency, and can reach the whole world.

Tourists use the internet to search for information about destinations which will be visited before making a purchase (Gupta \& Gulla, 2010). Tourists generally use the internet for booking travel products ranging from booking air tickets, accommodation services, even booking a tour package for food and drinks in certain restaurants. A similar explanation is described by a villa manager who says that most tourists make a reservation through the internet. Internet marketing is the main topic and the reason why almost all the nations of the world are very interested in the internet. Internet is an interactive medium where internet users can communicate without the limits of distance and time to reach the whole world.

Along with the rapid development and application of information technology, internet users have formed a new group of consumers who integrate the website into their daily lives. Websites and social media affect the way people communicate, make decisions, socialize, learn, entertain themselves, interact with each other, and even do shopping just by clicking a computer mouse. However, creating a website for independent villas better known by internet users and potential customers is a matter that requires considerable time and the costs are quite high.

OTA is an online travel agency business, which focuses on dealing with the sale of a variety of tourism products of various tourism businesses who are becoming partners. Tourism businesses are working with OTA ranging from the sale of flight services, business accommodation, and other tourism businesses. There are three major OTAs in Bali: agoda.com, booking.com, and expedia.com. In general, OTA has a way of working that is almost similar to each other.

Preliminary observations indicate that the number of reservations made through the villa's own website is still less than the number of reservations made via OTA. The average reservation via OTA per year reaches $70 \%-80 \%$. Travelers are more likely to make a reservation via OTA. Therefore, there is a tendency if the manager of the villa in North Kuta Kecamata makes promotion and sales through OTA media.

North Kuta district is the location with the highest number of villas among the districts in Badung, so it was decided to determine the location of the research in these districts. Therefore, it is necessary to do research related to the perception of a villa manager to use OTA as marketing media. Departing from the previous description, the purpose of the study is to identify and analyze the dominant factors forming villa managers' perceptions in North Kuta district on using OTA as a marketing medium. 


\section{Research Method}

\section{Research Location}

The study was conducted in the district of North Kuta, Badung Regency, Bali Province. Selection of this region as a location for research was done on purpose, based on the following considerations: (1) North Kuta district is a district that has the highest percentage of villas spread among other districts in Badung; and (2) There is a phenomenon of an increasing number of villa managers in the district of North Kuta using OTA as a medium for marketing when facing competition in grabbing customers.

\section{Type and Source of Data}

The data collected in this study are both quantitative and qualitative. Quantitative data are data expressed in numerical forms or figures, obtained directly from the field through the questionnaire, among others: the promotion effort, the data of indicators forming factors in the perception of villa managers in the district of North Kuta. Qualitative data are data that are expressed in the form of statements and descriptions of the villa managers in North Kuta district who act as informants in this study and other data.

The data are collected through both primary and secondary sources. From primary sources, we obtained primary data collected directly from primary sources, namely, respondents. Resulting from secondary sources are secondary data, namely, second-hand data or data collected from other sources which had been available before the study was conducted (Silalahi, 2012).

\section{Instrument and Method of Data Collection}

Data collection instrument used in the study was a questionnaire completed by the villa manager respondent and interview guide for some villa managers in North Kuta district.

Data collection methods used in this study include the observation method, questionnaire distribution method, interview method and literature review.

\section{Population and Research Sample}

The population in this study is composed of the villas which have a business license in the North Kuta district. Based on data of Badung Tourism Agency (2013), the total number of villas is 191. The final number of sample villas was determined using Slovin formula (Riduwan, 2010). With a population of as much as 191 villa units, the final number of obtained sample villas is 66 based on the calculation results of Slovin formula. One villa is represented by the respondent in this study, namely, the manager of the villa. So, the total number of respondents (villa managers) is 66. This amount is already qualified for the analysis of factors, which suggests using a sample of at least five times the number of variables or indicators.

In this research, informant as the source of qualitative data is also needed. The informants in this research are the ones who are competent in terms of promoting villas (the management of villas ranging from general manager, operations manager, marketing manager or sales and marketing managers, and supervisors, and a sales staff who is responsible for promotional activities of villa) for providing answers to the questions given during the interview. This interview aims to obtain information about the marketing details, especially promotion via OTA. The informants are determined using purposive sampling technique.

\section{Identification and Measurement of Variables/Indicators}

Table 1 below identifies the factors forming the villa manager's perceptions on using OTA and the indicators/variables forming factors based on the theory of Robbins and Judge (2008). Three factors, forming 
the perceptions of villa managers on using OTA, were identified: (1) a factor in the self-perception of villa manager (F1); (2) factor in the self-perception of OTA (F2); and (3) the perception factor of situation (F3). F1 is formed by five variables, F2 is formed by five variables, and F3 is formed by three variables (see Table 1).

Table 1

Factors and Variables Forming Villa Managers'Perceptions on Using OTA as Marketing Media in North Kuta District, Badung Regency, Bali, Indonesia

\begin{tabular}{|c|c|c|c|c|c|}
\hline No. & Factor & Variable/indicator & Notation & Measurement & Source \\
\hline \multirow{5}{*}{1} & \multirow{5}{*}{$\begin{array}{l}\text { Self-perception } \\
\text { of the villa } \\
\text { manager (F1) }\end{array}$} & $\begin{array}{l}\text { Attitude } \rightarrow \text { The villa managers think that OTA is a marketing } \\
\text { medium, especially promotion and sales for the } \\
\text { accommodation industry, in particular villa. }\end{array}$ & $\mathrm{X}_{1.1}$ & $\begin{array}{l}\text { Ordinal } \\
\text { (Likert scale) }\end{array}$ & \multirow{5}{*}{$\begin{array}{l}\text { Perception } \\
\text { theory by } \\
\text { Robbins and } \\
\text { Judge (2008, } \\
\text { pp. 175-176) }\end{array}$} \\
\hline & & $\begin{array}{l}\text { Motive } \rightarrow \text { Villa manager using the OTA for marketing } \\
\text { especially as promotion and sales is seen as a necessity. }\end{array}$ & $\mathrm{X}_{1.2}$ & $\begin{array}{l}\text { Ordinal } \\
\text { (Likert scale) }\end{array}$ & \\
\hline & & $\begin{array}{l}\text { Interest } \rightarrow \text { Villa manager is interested in marketing, } \\
\text { especially in promotion and sales via OTA. }\end{array}$ & $\mathrm{X}_{1.3}$ & \begin{tabular}{|l}
$\begin{array}{l}\text { Ordinal } \\
\text { (Likert scale) }\end{array}$ \\
\end{tabular} & \\
\hline & & $\begin{array}{l}\text { Experience } \rightarrow \text { Villa manager has experience in marketing } \\
\text { especially promotion and sales using OTA which has an } \\
\text { impact on the increase of occupancy rate of villas. }\end{array}$ & $\mathrm{X}_{1.4}$ & $\begin{array}{l}\text { Ordinal } \\
\text { (Likert scale) }\end{array}$ & \\
\hline & & $\begin{array}{l}\text { Hope } \rightarrow \text { Villa managers hope that marketing, especially } \\
\text { promotion through OTA, will increase the revenues of the } \\
\text { villas (increase of the occupancy rates of villas). }\end{array}$ & $\mathrm{X}_{1.5}$ & $\begin{array}{l}\text { Ordinal } \\
\text { (Likert scale) }\end{array}$ & \\
\hline \multirow{5}{*}{2} & \multirow{5}{*}{$\begin{array}{l}\text { Self-perception } \\
\text { of OTA (F2) }\end{array}$} & $\begin{array}{l}\text { Something new } \rightarrow \text { OTA is a new breakthrough in villa } \\
\text { marketing, especially promotion and sales online. }\end{array}$ & $\mathrm{X}_{2.1}$ & $\begin{array}{l}\text { Ordinal } \\
\text { (Likert scale) }\end{array}$ & \multirow{5}{*}{$\begin{array}{l}\text { Perception } \\
\text { theory by } \\
\text { Robbins and } \\
\text { Judge (2008, } \\
\text { pp. 175-176) }\end{array}$} \\
\hline & & $\begin{array}{l}\text { Perception of the front display/user interface } \rightarrow \text { Perception of } \\
\text { villa manager to performance of OTA. }\end{array}$ & $\mathrm{X}_{2.2}$ & $\begin{array}{l}\text { Ordinal } \\
\text { (Likert scale) }\end{array}$ & \\
\hline & & $\begin{array}{l}\text { OTA background } \rightarrow \text { The villa managers agreed if with the } \\
\text { big names of OTA, they will be able to boost the company’s } \\
\text { image so as to be better known by people. }\end{array}$ & $\mathrm{X}_{2.3}$ & $\begin{array}{l}\text { Ordinal } \\
\text { (Likert scale) }\end{array}$ & \\
\hline & & $\begin{array}{l}\text { Cooperation } \rightarrow \text { The villa managers conduct mutually } \\
\text { beneficial cooperation with the OTA. }\end{array}$ & $\mathrm{X}_{2.4}$ & $\begin{array}{l}\text { Ordinal } \\
\text { (Likert scale) }\end{array}$ & \\
\hline & & $\begin{array}{l}\text { Similarity of procedures for the use } \rightarrow \text { Use of OTA with each } \\
\text { other is essentially the same. }\end{array}$ & $\mathrm{X}_{2.5}$ & $\begin{array}{l}\text { Ordinal } \\
\text { (Likert scale) }\end{array}$ & \\
\hline \multirow{3}{*}{3} & \multirow{3}{*}{$\begin{array}{l}\text { Perception of } \\
\text { situation (F3) }\end{array}$} & $\begin{array}{l}\text { Time } \rightarrow \text { Perception of the villa manager looked at is the trend } \\
\text { of using OTA as the booking channels of accommodation } \\
\text { services (villa). }\end{array}$ & $\mathrm{X}_{3.1}$ & $\begin{array}{l}\text { Ordinal } \\
\text { (Likert scale) }\end{array}$ & \multirow{3}{*}{$\begin{array}{l}\text { Perception } \\
\text { theory by } \\
\text { Robbins and } \\
\text { Judge (2008, } \\
\text { pp. 175-176) }\end{array}$} \\
\hline & & $\begin{array}{l}\text { Working condition } \rightarrow \text { Perception of villa managers regarding } \\
\text { better internet access, causing the increasing use of OTA as } \\
\text { marketing media, especially promotion and sales. }\end{array}$ & $\mathrm{X}_{3.2}$ & $\begin{array}{l}\text { Ordinal } \\
\text { (Likert scale) }\end{array}$ & \\
\hline & & $\begin{array}{l}\text { Social condition } \rightarrow \text { Perception of villa managers regarding } \\
\text { internet access that is easy to cause potential customers to } \\
\text { book rooms via OTA. }\end{array}$ & $\mathrm{X}_{3.3}$ & $\begin{array}{l}\text { Ordinal } \\
\text { (Likert scale) }\end{array}$ & \\
\hline
\end{tabular}

Measurement of each variable factor forming perception is based on a 5-point Likert scale, ranging from 5 = very agree (very positive), 4 = agree (positive), 3 = neutral (usual), 2 = disagree (negative), to 1 = very disagree (very negative). To be able to categorize the average value of the variables of motivation that is a fraction, then the Likert scale can also be made in the form of class intervals, ranging from 4.2-5 = very agree (very positive), $3.4-<4.2=$ agree (positive), $2.6-<3.4=$ neutral (usual), $1.8-<2.6=$ disagree (negative), to $1-<1.8$ = very disagree (very negative).

\section{Analysis of Data}

Descriptive statistics were used to analyze numerical data which are addition, subtraction or find the average value as the level of perception, which do not do the test, so as to describe the level of a villa manager's perception in North Kuta district, Badung regency, Bali. 
Analysis of factors forming the perception of villa managers in the district of North Kuta on using OTA as marketing media, especially promotion and sales using confirmatory factor analysis method, has been done with SPSS 21. According to Santoso (2014), the process of factor analysis includes several stages of testing the factors forming perception, testing variables forming factor, and interpreting the results of confirmatory factor analysis.

Qualitative descriptive narrative was made based on the results of factor analysis and in-depth interviews about the intricacies of villa marketing through OTA conducted by villa managers in the North Kuta district, Badung, Bali.

\section{Results and Discussion}

\section{Perception Levels of Villa Managers on the Use of OTA}

Based on the results of descriptive statistical analysis, the general perception of the villa manager in the North Kuta district on using OTA as a marketing medium is very much agree with the perception of the average value of 4.37 (see Table 2). It means that the villa managers agree very much in marketing the villa using OTA, as they feel that the perceived advantages are more than the disadvantages. The average rating of the three factors is as follows: (1) perception factor of the situation has a score of 4.48; (2) factor in the self-perception of villa manager has a score 4.42; and (3) factor in the self-perception of OTA has a score of 4.23 (see Table 2).

Factor of situation perception (F3) obtained the highest score (average score of 4.48), which is caused by the high factor scores of the three variables/statements forming the perception of situation: the time, working condition, and social condition. For example, in the case of variable time, the villa manager sees it as a trend to use OTA as a booking channel of accommodation services (villa). In the case of variable working condition, in which the villa managers think that internet access has become better, so the use of OTA as a marketing medium has increased. In the case of variable social condition, the villa managers think that easy internet access is easy to cause potential customers to book room via OTA.

Self-perception of the villa manager (F1) received the second highest average score (4.42), meaning that the villa manager respondents in the North Kuta district are very positive or agree very much about the use of OTA as a villa marketing medium. This is caused by the positive rating of attitudes, motives, interests, experiences, and expectations of villa managers on using OTA as a villa marketing medium. For example, attitude variable, the villa managers think that OTA is a marketing medium for the accommodation industry, in particular villa. Motive variable, the villa managers use OTA to do marketing which is seen as a necessity. Variable of interest, the villa managers are interested in doing marketing, especially the promotion and sales via OTA. Experience variable, the villa managers have the experience of marketing using OTA which has an impact on the increasing occupancy rate of villas. Expectation variable, the villa managers hope that marketing via OTA will increase the revenues of villas (increase of the occupancy rates of villas).

Factor of the self-perception of OTA (F2) obtains the lowest average score (4.23), but it is still in very agree or very positive category. This is caused by the high average value scores of the variables forming the factor of self-perception of OTA, namely, something new, the front display/user interface of OTA, background of OTA, cooperation of villas with OTA, and the similarity of procedures using OTA, e.g.: something new villa manager considers OTA as a new breakthrough in the online marketing effort; the front display/user 
interface - the manager of the villa looked OTA look interesting to visit; background of OTA - the villa managers agreed if with the big names of OTA, they will be able to boost the company's image so as to be better known by people; cooperation of villas with OTA - the villa managers conduct mutually beneficial cooperation with the OTA; and similarities of procedure for the use of OTA - the use of OTA with each other is essentially the same.

Table 2

Perception Level of Villa Managers on the Use of OTA in the North Kuta District, Badung Regency, Bali, Indonesia

\begin{tabular}{llll}
\hline Factor & No. & Variable & Average score \\
\hline & 1 & Attitude $\left(\mathrm{X}_{1.1}\right)$ & 4.53 \\
& 2 & Motive $\left(\mathrm{X}_{1.2}\right)$ & 4.27 \\
Self-perception of villa managers (F1) & 3 & Interest $\left(\mathrm{X}_{1.3}\right)$ & 4.27 \\
& 4 & Experience $\left(\mathrm{X}_{1.4}\right)$ & 4.55 \\
& 5 & Hope $\left(\mathrm{X}_{1.5}\right)$ & 4.47 \\
\hline Average & & & 4.42 \\
\hline & 1 & Something new $\left(\mathrm{X}_{2.1}\right)$ & 4.41 \\
Self-perception of OTA (F2) & 2 & Perception front view/user interface $\left(\mathrm{X}_{2.2}\right)$ & 4.35 \\
& 3 & OTA background $\left(\mathrm{X}_{2.3}\right)$ & 4.44 \\
& 4 & Cooperation $\left(\mathrm{X}_{2.4}\right)$ & 4.08 \\
Average & 5 & Similarities of procedures for the use $\left(\mathrm{X}_{2.5}\right)$ & 3.85 \\
\hline & & & 4.23 \\
Perception of situation (F3) & 1 & Time $\left(\mathrm{X}_{3.1}\right)$ & 4.39 \\
& 2 & Working condition $\left(\mathrm{X}_{3.2}\right)$ & 4.55 \\
\hline Average & 3 & Social condition $\left(\mathrm{X}_{3.3}\right)$ & 4.50 \\
\hline General average & & 4.48 \\
\hline
\end{tabular}

Note. The value of the average score of each variable/indicator is based on 66 villa manager respondents.

\section{Factors Forming the Perception of Villa Managers on Using OTA}

We conducted a simultaneous analysis of the three factors forming the perception of villa managers in the district of North Kuta on the use of OTA, which is the combined score of variables comprising: self-perception of villa manager factor, self-perception of OTA factor, and situational factors. The result shows that all the factors included in the model deserve to be factored, in other words, the three factors are indeed forming the perceptions of villa managers on the use of OTA, which is shown by Kaiser-Meyer-Olkin (KMO) value of $0.718(>0.5)$, which is significant at the level of error $5 \%(p=0.000<p$-table 0.05$)$, so the factor analysis can proceed (Dillon \& Goldstein, 1984). Thus, the perception factor of villa managers in the North Kuta district on the use of OTA as a marketing medium was completely determined by three factors: self-perception of villa manager factor (F1), self-perception of OTA factor (F2), and situational factors (F3) (see Table 3, Part 1). Feasibility of the three factors F1, F2, and F3 forming factor perception was also justified by the results of anti-image correlation analysis between factors F1, F2, and F3, which is more than 0.5 (see Table 3, Part 2), meaning that the factors F1, F2, and F3 have a very significant statistical correlation with the anti-image correlation value. 
Table 3

Statistics Values of Factors Forming the Perceptions of Villa Managers on Using OTA in North Kuta District, Badung Regency, Bali, Indonesia

\begin{tabular}{llc}
\hline \multicolumn{2}{c}{ Part 1: KMO and Bartlett's test results of perception factor $\rightarrow$ justification forming the factors } \\
\hline Measure of sampling adequacy & & 0.718 \\
\hline \multirow{3}{*}{ Bartlett's test of sphericity } & Approx. chi-square & 107.376 \\
& Df & 3 \\
& Sig. & 0.000 \\
\hline
\end{tabular}

\begin{tabular}{|c|c|c|c|c|}
\hline \multicolumn{5}{|c|}{ Part 2: Matrix correlations between variables forming the perception factors $\rightarrow$ correlation factor with anti-image } \\
\hline & Factor & F1 & F2 & F3 \\
\hline \multirow{3}{*}{ Anti-image covariance } & F1 & 0.352 & -0.209 & -0.088 \\
\hline & F2 & -0.209 & 0.311 & -0.154 \\
\hline & F3 & -0.088 & -0.154 & 0.496 \\
\hline \multirow{3}{*}{ Anti-image correlation } & F1 & $0.702^{\mathrm{a}}$ & -0.633 & -0.210 \\
\hline & $\mathrm{F} 2$ & -0.633 & $0.668^{\mathrm{a}}$ & -0.392 \\
\hline & F3 & -0.210 & -0.392 & $0.819^{\mathrm{a}}$ \\
\hline
\end{tabular}

Part 3: The communality of variables of perception factor $\rightarrow$ influence (\%) of each factor F1, F2, and F3 on villa manager's perception

\begin{tabular}{lrr}
\hline F1 (Factors in the self-perception of villa manager) & 1.000 & 0.823 \\
F2 (Factors in the self-perception of OTA) & 1.000 & 0.858 \\
F3 (Factors of situation) & 1.000 & 0.742 \\
\hline
\end{tabular}

Part 4: Eigenvalue, percentage of variance, and cumulative percentage of variance of the three variables forming the perception factors $\rightarrow$ contribution of factor forming the perception (\%) and a significance level of characteristic roots (eigenvalues)

\begin{tabular}{|c|c|c|c|c|c|c|}
\hline \multirow{2}{*}{ Component } & \multicolumn{3}{|c|}{ Initial eigenvalues } & \multicolumn{3}{|c|}{ Extraction sums of squared loadings } \\
\hline & Total & \% of variance & Cumulative $\%$ & Total & $\%$ of variance & Cumulative \% \\
\hline 1 & 2.423 & 80.759 & 80.759 & 2.423 & 80.759 & 80.759 \\
\hline 2 & 0.377 & 12.582 & 93.340 & & & \\
\hline 3 & 0.200 & 6.660 & 100.000 & & & \\
\hline
\end{tabular}

Part 5: Matrix of perception factors with varimax rotation $\rightarrow$ Correlation of each factor F1, F2, and F3 of the factors forming villa managers' perception (joint factor)

\begin{tabular}{ll}
\hline Factor & Component \\
\hline & 1 \\
F1 (Factors in the self-perception of villa manager) & 0.907 \\
F2 (Factors in the self-perception of OTA) & 0.926 \\
F3 (Factors of situation) & 0.861 \\
\hline
\end{tabular}

Note. $^{\text {a}}$ : indicates the highest coefficient of anti-image correlation in each column.

The contribution of each factor F1, F2, and F3 to the perceptions of villa managers in the North Kuta district on using OTA as a marketing medium, especially in the promotion and sales, can be explained by the value of communality of each factor, namely, the factor of self-perception of villa manager (F1) amounted to $82.3 \%$, a factor in the self-perception of OTA (F2) of $85.8 \%$, and the situation factor (F3) amounted to $74.2 \%$ (see Table 3, Part 3). While the joint contribution of factors F1, F2, and F3 in forming the perception of villa managers in the district of North Kuta on using OTA is equal to $80.759 \%$ of the total variance, which means that perception of villa manager formed by one factor representing the three factors F1, F2, and F3 with values characteristic roots (eigenvalues) is 2.423 (> 1.00) (see Table 3, Part 4). The correlation of each factor F1, F2, and F3 by factors formed (joint factor), namely, the factor in the self-perception of OTA (F2) has the strongest correlation with the construct of perception (correlation coefficient $=0.926$ ), followed by factor in the self-perception of villa manager $(\mathrm{F} 1)$ (correlation coefficient $=0.907$ ), and the weakest correlation is the factor of situation $(\mathrm{F} 3)$ (correlation coefficient $=0.861)$ (see Table 3, Part 5). 
Based on the results of the joint factor analysis, these three factors of self-perception of villa manager (F1), the self-perception of OTA (F2), and the perception of the situation (F3) indeed form the very positive perceptions of the villa managers in the North Kuta district on the use of OTA as marketing media, especially as promotion and sales media. However, each of these factors has a different contribution to forming the perception of managers on the use of OTA, in which the highest contributor was the factor perception of the situation, followed by a factor in the self-perception of villa manager, and the lowest contributor was a factor in the self-perception of OTA.

Villa managers are aware of the benefits in using OTA as marketing media, especially promotion and sales media. This is demonstrated by the seriousness of the villa which has a section or a specialized staff who handles online promotions, commonly called e-commerce officer. Direct interviews with villa managers in the district of North Kuta on the social state variables can help us obtain information that the villas managers in the North Kuta district who are in cooperation with OTA can run easier, cheaper and time-saving, even so the managers still work with offline travel agents. As for the time variable, we obtained information that today's travelers are more likely to make their own reservations online through OTA or independent website of the villas.

\section{Conclusions and Recommendations}

\section{Conclusions}

After conducting the factor analysis, we finally reach the following conclusions:

(1) In general, the perception of villa managers in the district of North Kuta on the use of OTA as marketing media, especially promotion and sales media, is very agree or very positive with an average value of 4.37. The highest average rating is the factor of situation perception (score: 4.48), followed by factor in the self-perception of villa manager (score: 4.42) and the factor in the self-perception of OTA (score: 4.23);

(2) The analysis of factors simultaneously shows that indeed, the perception of villa managers in the district of North Kuta on the use of OTA is determined by three factors: factor in the self-perception of villa manager (F1), factor in the self-perception of OTA (F2), and situational factors (F3).

\section{Recommendations}

For future research, we recommend the following:

(1) The villa managers should recruit the special staff to handle OTA toward the availability of data or availability of villas, especially if the villa uses more than one OTA to avoid over booking;

(2) The villa managers should maintain and constantly improve the service, ensuring the comfort and safety of tourists to avoid the negative comments written by tourists on OTA. Negative comments will tend to lower the ranking of the villa, and vice versa if the tourists are satisfied, they will give positive comments, which will increase the sales revenue of the villa;

(3) The online promotion should not only focus on using OTA, but still should also maintain an independent villa website. Because the reservations made by tourists through the independent websites of villas will certainly bring them higher net sales when compared with the reservations made through OTA.

\section{References}

Badung Tourism Agency. (2013). Business license published January 1, 2009 until July 8, 2013. Published by Badung Tourism Agency, Bali, Indonesia.

Dillon, W. R., \& Goldstein, M. (1984). Multivariate analysis: Methods and applications. New York, NY: John Wiley \& Sons. 
Evita, R., Sirtha, I. N., \& Sunarta, I. N. (2012). Dampak Perkembangan Pembangunan Sarana Akomodasi Wisata Terhadap Pariwisata Berkelanjutan di Bali. Penerbit Universitas Udayana, Denpasar, Bali.

Gupta, K., \& Gulla, A. (2010). Internet deployment in the spiritual tourism industry: The case of Vaishno Devi Shrine. Worldwide Hospitality and Tourism Themes, 2(5), 507-519.

Ismoyo, S. S. (2011). Pengaruh Pelayanan, Hargadan Biaya Promosi Terhadap Online Booking (Tesis Tidak Dipublikasi, Universitas Udayana, Bali, Indonesia).

Kotler, P. (2000). Marketing management: Millenium edition (10th ed.). Upper Saddle River, NJ: Prentice Hall, Inc..

Kotler, P., \& Armstrong, G. (2012). Principles of marketing. Upper Saddle River, NJ: Prentice Hall, Inc..

Riduwan. (2010). Method and technique of thesis compiling. Penerbit Alfabeta, Bandung.

Robbins, S. P., \& Judge, T. A. (2008). Organizational behaviour (Cited by Diana Angelica, Ria Cahyanidan Abdul Rosyid, Pentj). Jakarta: Salemba Empat. Retrieved from http://books.google.co.id

Santoso, S. (2014). Multivariate statistic, concept and application with the SPSS. Jakarta: Publisher Elex Media Computindo.

Silalahi, U. (2012). Metode Penelitian Sosial. Penerbit Refika Aditama, Bandung. 